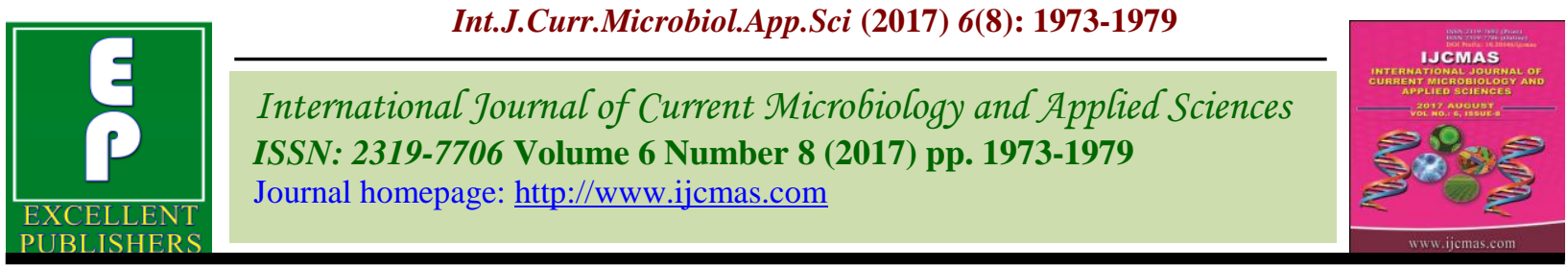

Original Research Article https://doi.org/10.20546/ijcmas.2017.608.234

\title{
Microbiological and Sensory Stability of Preserved Mango (Mallika) Pulp during Storage
}

\section{Manisha Jangir ${ }^{1 *}$, Virendra Singh ${ }^{1}$, Pramila Kumari ${ }^{1}$, Sukhdev Singh ${ }^{1}$ and Deepak Kumar Sarolia ${ }^{2}$}

${ }^{1}$ Department of Horticulture, RCA, MPUAT, Udaipur, Rajasthan, India

${ }^{2}$ CIAH, Bikaner (Rajasthan), India

*Corresponding author

\section{A B S T R A C T}

This study was carried out to evaluate the best preservation way for mango pulp preservation. For this the pulp of mango were preserved with thirteen different treatment combinations viz., pulp preserved with potassium meta-bisulphite $0.05 \%\left(\mathrm{~T}_{1}\right)$, pulp preserved with potassium meta-bisulphite $0.1 \%\left(\mathrm{~T}_{2}\right)$, pulp preserved with sodium benzoate $0.05 \%\left(\mathrm{~T}_{3}\right)$, pulp preserved with sodium benzoate $0.1 \%\left(\mathrm{~T}_{4}\right)$, pulp preserved with sodium

Keywords

Mango pulp,

Preservation,

CFU, Sensory

evaluation.

Article Info

Accepted:

19 June 2017

Available Online:

10 August 2017 meta-bisulphite $0.05 \%\left(\mathrm{~T}_{5}\right)$, pulp preserved with sodium meta bi-sulphite $0.1 \%\left(\mathrm{~T}_{6}\right)$, pulp preserved with potassium sorbate $0.05 \%\left(\mathrm{~T}_{7}\right)$, pulp preserved with potassium sorbate 0.1 $\%\left(\mathrm{~T}_{8}\right)$, pulp preserved with sodium benzoate + potassium sorbate $0.05 \%$ each $\left(\mathrm{T}_{9}\right)$, pulp preserved with potassium meta bi-sulphite + potassium sorbate $0.05 \%$ each $\left(\mathrm{T}_{10}\right)$, pulp preserved with sodium meta bi-sulphite + potassium sorbate $0.05 \%\left(\mathrm{~T}_{11}\right)$, refrigeration $4 \pm 2^{\circ} \mathrm{C}\left(\mathrm{T}_{12}\right)$, frozen storage $-20^{\circ} \mathrm{C}\left(\mathrm{T}_{13}\right)$, These treatment combinations were evaluated under completely randomized design with four replications. The results revealed that preserved pulp at $-20^{\circ} \mathrm{C}$ ) was better with over all sensory attributes viz., taste, flavour and aroma. Significant inhibition of the total bacterial count (TBC) and total fungal count (TFC) were observed on applying the specified concentrations, however minimum microbes growth was observed under frozen storage at $-20^{\circ} \mathrm{C}$. All parameters of samples were observed at fortnight interval during storage (up to 90 days) and at end of storage acceptable pulp were used for different products (RTS, Squash and jam) preparation and analysed its quality. Storage time significantly $(\mathrm{p}<0.05)$ increased the CFU/g of the pulp samples as the maximum growth was observed after 90 days of storage. Sensory characteristics of the juice prepared from treated mango pulp samples were affected negatively on addition of preservatives and temperature, however, the samples were accepted by the judges even after three months of storage.

\section{Introduction}

Mango (Mangiferaindica L.) is one of the most important fruit crops of India having socio-economic significance. It belongs to family Anacardiaceae and originated from South-East Asia. Mango ranks second after banana with annual production 185.05 million tons from an area of 22.16 million hectare with an average productivity of $7.3 \mathrm{MT}$.
(Saxena et al., 2015). Mango fruit is widely accepted by consumers throughout the world for its succulence, sweet taste and exotic flavor, being called "The King of fruits". The fruits are consumed fresh and largely used in the food industry for the production of canned fruits, jam and concentrated juice (Tharanathan et al., 2006). The mango fruit is 
popular in international market due to its excellent flavour, attractive fragrance, beautiful colour, delicious taste and nutritional properties (Sivakumar et al., 2011).

Mango is a short seasoned fruit and being highly perishable does not withstand even in cold storage. Therefore, most of the fruit processing industries preserve mango pulp for the manufacture of mango products round the year.

Mango pulp is not generally consumed directly rather used as fillings for pastries, jams, sauces, fruit juices and drinks (Hussain et al., 2003). The mango pulp is highly prone to microbial contamination due to high moisture content hence, pulp is having shortest shelf life.

Therefore, the efforts have been made in the present investigation in order to improve the shelf life of mango pulp by using the various safe preservatives and with their optimum concentrations and temperature variations.

The chemical preservatives are used to prevent the food spoilage due to microbial attack and thus are effectively used in combinations for better preservation. No single preservative is completely effective against all microorganisms. Sodium benzoate (SB) and potassium metabisulphite (PMS) are commonly used as preservatives for long term storage of fruit pulp because of their better antimicrobial activity.

The present work was carried out in order to investigate the inhibitory effect of different preservatives and temperature in controlling the growth and survival of microflora of mango pulp stored under ambient conditions. The study further explored the effect of storage in mango pulp on physico chemical characteristics and its sensory attributes.

\section{Materials and Methods}

The experiment was carried out in PostHarvest Lab, Department of Horticulture, Rajasthan College of Agriculture, MPUAT, Udaipur (Rajasthan) during May to October, 2016. Fully mature and ripe mango $c v$. Mallika fruits procured from Agriculture Research Station, Banswara (Rajasthan) were used for experimentation. After bringing the fruits from the farm diseased, damaged and off type fruits were discarded. Fresh and physiologically mature mango fruits were washed with tap water to remove dirt and dust particles adhering to the surface of fruits and crushed for obtaining pulp. For the preservation of mango pulp, after washing, peeling and coring the flesh was cut into small pieces with stainless steel knives and pulp was made by using electric blender. After addition of water in 2:1, pulp was homogenized and passed through fine mesh to get uniform textured pulp. Pulp was then pasteurized in a water bath at a temperature of $82 \pm 2^{\circ} \mathrm{C}$ for 30 minutes to reduce the microbial load.

Obtained pulp was preserved with thirteen different treatments namely, pulp preserved with potassium meta-bisulphite $0.05 \%\left(\mathrm{~T}_{1}\right)$, pulp preserved with potassium metabisulphite $0.1 \%\left(\mathrm{~T}_{2}\right)$, pulp preserved with sodium benzoate $0.05 \%\left(\mathrm{~T}_{3}\right)$, pulp preserved with sodium benzoate $0.1 \% \quad\left(\mathrm{~T}_{4}\right)$, pulp preserved with sodium meta-bisulphite $0.05 \%$ $\left(\mathrm{T}_{5}\right)$, pulp preserved with sodium meta bisulphite $0.1 \% \quad\left(\mathrm{~T}_{6}\right)$, pulp preserved with potassium sorbate $0.05 \%\left(\mathrm{~T}_{7}\right)$, pulp preserved with potassium sorbate $0.1 \% \quad\left(\mathrm{~T}_{8}\right)$, pulp preserved with sodium benzoate + potassium sorbate $0.05 \%$ each $\left(\mathrm{T}_{9}\right)$, pulp preserved with potassium meta bi-sulphite + potassium sorbate $0.05 \%$ each $\left(\mathrm{T}_{10}\right)$, pulp preserved with sodium meta bi-sulphite + potassium sorbate $0.05 \%\left(\mathrm{~T}_{11}\right)$, refrigeration $4 \pm 2^{\circ} \mathrm{C}$ $\left(\mathrm{T}_{12}\right)$, frozen storage $-20^{\circ} \mathrm{C} \quad\left(\mathrm{T}_{13}\right)$ and 
replicated thrice. Physico-chemical parameters of samples were observed at 0,15 , $30,45,60,75,90$ days of storage.

\section{Microbiological assay}

The determination of the total microbial contamination of the pulp samples was performed at fortnight interval until three months by the method.Thornton's medium was used for periodical determination of total bacterial count (TBC) in the stored mango pulp sample. Thornton's medium was suspended/litre of distilled water, mixed thoroughly, $\mathrm{pH}$ adjusted at $7.2\left(25^{\circ} \mathrm{C}\right)$, heated with frequent agitation and boiled for 1 minute to completely dissolve the ingredients and autoclaved at $121.5^{\circ} \mathrm{C}$ for 15 minutes. 10 g sample was taken from each treated pulp sample using aseptic techniques and added in $95 \mathrm{ml}$ sterile water blank in $500 \mathrm{ml}$ conical flask. $1 \mathrm{ml}$ pulp sample obtained in the previous step was transferred into $9 \mathrm{ml}$ sterile water blank in test tube. Continue the series in similar manner to get upto $10^{-4}$ dilution level for fungi and $10^{-6}$ dilution level for bacteria. 1 $\mathrm{ml}$ of required dilution transferred into sterile petri plates i.e. already poured by the required media for specific organisms.

The contents were mixed thoroughly and aliquots were serially diluted and enumerated onto Thornton's media for bacteria and Martin's rose bengal media for fungi. Plates were incubated in inverted position at $28^{\circ} \mathrm{C}$ in incubator for 2 days for fungi and 4 days for bacteria and count the number of colonies and multiplied by the respective dilution factor to obtain number of viable cells $\mathrm{g}^{-1}$ pulp.

\section{Sensory evaluation of mango pulp samples}

The pulp was evaluated organoleptically by a panel of five judges by Hedonic Rating Test (Amerineet al., 1965). Regarding the colour, flavor, texture, taste and overall acceptability of the pulp was also evaluated. The score was expressed on 0-9 scale and averaged.

\section{Hedonic rating test}

The judges were provided with prescribed questionnaires to record their observation. The information contained on the performa was $9=$ Like extremely; $8=$ Like very much; 7 = Like moderately; $6=$ Like slightly; $5=$ Neither like nor dislike; 4 = Dislike slightly; 3 $=$ Dislike moderately; 2 = Dislike very much; $1=$ Dislike extremely.

The data were analyzed by using Completely Randomized Design (Fisher, 1950).

\section{Results and Discussion}

\section{Microbial growth}

Table 1 (Fig. 1) indicates that the bacterial growth of preserved mango pulp increased with the advancement of storage duration. It was significantly affected by preservatives and temperature from 15 and 90 days of storage duration. The minimum bacterial growth was recorded from treatment $\mathrm{T}_{13}$ frozen storage at $-20^{\circ} \mathrm{C} \quad\left(2.70 \times 10^{-6} \mathrm{~g}^{-1}\right)$ followed by $\mathrm{T}_{2}$-KMS@0.1\% $\left(2.90 \times 10^{-6} \mathrm{~g}^{-1}\right)$ and maximum bacterial growth from $\mathrm{T}_{7}$-PS@ $0.05 \%\left(7.20 \times 10^{-6} \mathrm{~g}^{-1} \mathrm{cfu}\right) . \mathrm{T}_{2^{-}} \mathrm{KMS} 00.1 \%$ and $\mathrm{T}_{13}$-frozen storage at $-20^{\circ} \mathrm{C}$ were statistically at par with each other.

The data given in table 2 (Fig. 2) revealed that fungal growth on preserved mango pulp was increased as the storage duration increased. It was significantly affected from 15 to 90 days of storage duration. Among the treatments, the minimum fungal growth was recorded from treatment $\mathrm{T}_{13}$-frozen storage at $-20^{\circ} \mathrm{C}$ $\left(2.30 \times 10^{-4} \mathrm{~g}^{-1}\right)$ followed by $\mathrm{T}_{2}$-KMS@ $0.1 \%$ $\left(4.30 \times 10^{-4} \mathrm{~g}^{-1}\right.$ and maximum fungal growth from $\quad \mathrm{T}_{7}$-PS@0.05\% $\quad\left(8.80 \quad \times 10^{-4} \quad \mathrm{~g}^{-1}\right)$ respectively. Treatment $\mathrm{T}_{2}(\mathrm{KMS} @ 0.1 \%)$ and 
$\mathrm{T}_{13}$-frozen storage at $-20^{\circ} \mathrm{C}$ was statistically at par with each other.

Lower bacterial growth at $-20^{\circ} \mathrm{C}$ is probably due to minimum physiological activities and respiration rate of microbes and ice-formation of cells at frozen temperature. Periodical analysis of the mango pulp samples for the TBC showed a progressive increase in the growth though the rate of growth varied with different treatment combinations except frozen storage followed by KMS and then SB. The results of the present study substantiated that none of the preservatives used was able to completely inhibit the bacterial growth in the specified concentrations for a period of 90 days storage; however, the preservative had been synergistically active in inhibition of the microbial growth in the pulp samples.

The present study is in agreement with Durrani et al., (2011), Hashmi et al., (2007) in mango pulp, Yadav et al., (2017) in guava pulp where minimum growth of fungus was observed in frozen storage treatment at $-20^{\circ} \mathrm{C}$ upto 90 days of storage, Ayub et al., (2010) in strawberry juice and Khattak et al., (2014) in apricot pulp.

Table.1 Effect of different preservatives and temperatures on bacterial growth (cfu X $10^{6} \mathrm{~g}^{-1}$ ) of Mango pulp during storage

\begin{tabular}{lccccccc}
\hline Treatments & \multicolumn{7}{c}{ Storage duration (days) } \\
\cline { 2 - 7 } & $\mathbf{0}$ & $\mathbf{1 5}$ & $\mathbf{3 0}$ & $\mathbf{4 5}$ & $\mathbf{6 0}$ & $\mathbf{7 5}$ & $\mathbf{9 0}$ \\
\hline $\mathrm{T}_{1}$ (KMS@ 0.05\%) & 0.00 & 0.90 & 1.90 & 2.10 & 2.40 & 2.80 & 3.10 \\
$\mathrm{~T}_{2}$ (KMS@ 0.1\%) & 0.00 & 0.80 & 1.70 & 1.90 & 2.20 & 2.60 & 2.90 \\
$\mathrm{~T}_{3}$ (SB@ 0.05\%) & 0.00 & 1.20 & 1.90 & 2.40 & 3.40 & 4.10 & 4.90 \\
$\mathrm{~T}_{4}$ (SB 0.1\%) & 0.00 & 1.10 & 1.70 & 2.10 & 3.10 & 3.70 & 4.60 \\
$\mathrm{~T}_{5}$ (SMS@ 0.05\%) & 0.00 & 1.20 & 2.30 & 2.60 & 3.10 & 3.50 & 3.80 \\
$\mathrm{~T}_{6}$ (SMS@ 0.1\%) & 0.00 & 1.10 & 2.30 & 2.50 & 2.80 & 3.20 & 3.60 \\
$\mathrm{~T}_{7}$ (PS@ 0.05\%) & 0.00 & 1.40 & 2.30 & 3.40 & 4.70 & 5.70 & 7.20 \\
$\mathrm{~T}_{8}$ (PS@ 0.1\%) & 0.00 & 1.10 & 2.10 & 3.20 & 3.70 & 4.20 & 4.50 \\
$\mathrm{~T}_{9}$ (SB+PS@ 0.05\% each) & 0.00 & 1.10 & 2.10 & 2.30 & 3.20 & 3.80 & 4.70 \\
$\mathrm{~T}_{10}$ (KMS+PS@ 0.05\% each) & 0.00 & 1.20 & 1.90 & 2.00 & 2.30 & 2.70 & 3.00 \\
$\mathrm{~T}_{11}$ (SMS+PS@ 0.05\% each) & 0.00 & 1.10 & 2.30 & 2.50 & 3.00 & 3.20 & 3.70 \\
$\mathrm{~T}_{12}$ (Refrigeration $\left(4 \pm 2^{\circ} \mathrm{C}\right)$ & 0.00 & 0.90 & 1.40 & 1.80 & 2.40 & 2.90 & 3.30 \\
$\mathrm{~T}_{13}$ (Frozen storage -20 $\left.{ }^{\circ} \mathrm{C}\right)$ & 0.00 & 0.70 & 1.30 & 1.60 & 2.10 & 2.30 & 2.70 \\
$\mathrm{SEm}$ (SE & 0.00 & 0.02 & 0.05 & 0.05 & 0.05 & 0.06 & 0.09 \\
$\mathrm{C} . \mathrm{D}$. (P=0.05) & $\mathrm{NS}$ & 0.07 & 0.14 & 0.15 & 0.13 & 0.16 & 0.27 \\
\hline
\end{tabular}

Table.2 Effect of different preservatives and temperatures on fungal growth (cfu X $10^{4} \mathrm{~g}^{-1}$ ) of Mango pulp during storage

\begin{tabular}{|c|c|c|c|c|c|c|c|}
\hline \multirow[t]{2}{*}{ Treatments } & \multicolumn{7}{|c|}{ Storage duration (days) } \\
\hline & $\mathbf{0}$ & 15 & 30 & 45 & 60 & 75 & 90 \\
\hline $\mathrm{T}_{1}(\mathrm{KMS} @ 0.05 \%)$ & 0.00 & 1.20 & 1.70 & 2.30 & 2.70 & 4.40 & 4.90 \\
\hline $\mathrm{T}_{2}(\mathrm{KMS} @ 0.1 \%)$ & 0.00 & 1.10 & 1.60 & 2.10 & 2.60 & 3.20 & 4.30 \\
\hline $\mathrm{T}_{3}(\mathrm{SB} @ 0.05 \%)$ & 0.00 & 1.30 & 1.90 & 2.70 & 4.30 & 5.70 & 6.10 \\
\hline $\mathrm{T}_{4}(\mathrm{SB} @ 0.1 \%)$ & 0.00 & 1.20 & 1.70 & 2.40 & 3.90 & 5.50 & 5.80 \\
\hline $\mathrm{T}_{5}$ (SMS@0.05\%) & 0.00 & 1.40 & 1.90 & 2.70 & 4.10 & 5.60 & 6.30 \\
\hline $\mathrm{T}_{6}(\mathrm{SMS} @ 0.1 \%)$ & 0.00 & 1.30 & 1.90 & 2.60 & 3.80 & 5.20 & 5.80 \\
\hline $\mathrm{T}_{7}(\mathrm{PS} @ 0.05 \%)$ & 0.00 & 1.60 & 3.10 & 3.60 & 6.30 & 7.30 & 8.80 \\
\hline $\mathrm{T}_{8}$ (PS@0.1\%) & 0.00 & 1.20 & 2.10 & 2.30 & 3.10 & 5.30 & 5.60 \\
\hline $\mathrm{T}_{9}(\mathrm{SB}+\mathrm{PS} @ 0.05 \%$ each $)$ & 0.00 & 1.30 & 1.80 & 2.60 & 4.10 & 5.50 & 6.00 \\
\hline $\mathrm{T}_{10}(\mathrm{KMS}+\mathrm{PS} @ 0.05 \%$ each $)$ & 0.00 & 1.50 & 1.70 & 2.20 & 2.50 & 4.30 & 4.60 \\
\hline $\mathrm{T}_{11}(\mathrm{SMS}+\mathrm{PS} @ 0.05 \%$ each$)$ & 0.00 & 1.20 & 1.90 & 2.60 & 4.00 & 5.30 & 5.60 \\
\hline $\mathrm{T}_{12}$ (Refrigeration $\left(4 \pm 2^{\circ} \mathrm{C}\right)$ & 0.00 & 1.10 & 1.80 & 2.10 & 2.70 & 3.30 & 4.70 \\
\hline $\mathrm{T}_{13}\left(\right.$ Frozen storage $\left.-20^{\circ} \mathrm{C}\right)$ & 0.00 & 1.10 & 1.70 & 1.90 & 2.00 & 2.10 & 2.30 \\
\hline $\mathrm{SEm} \pm$ & 0.00 & 0.03 & 0.05 & 0.05 & 0.06 & 0.09 & 0.13 \\
\hline C.D. $(\mathrm{P}=0.05)$ & NS & 0.08 & 0.14 & 0.16 & 0.16 & 0.25 & 0.37 \\
\hline
\end{tabular}


Table.3 Effect of different preservatives and temperatures on taste of mango pulp during storage

\begin{tabular}{|c|c|c|c|c|c|c|c|}
\hline \multirow[t]{2}{*}{ Treatments } & \multicolumn{7}{|c|}{ Storage duration (days) } \\
\hline & $\mathbf{0}$ & 15 & 30 & 45 & 60 & 75 & 90 \\
\hline $\mathrm{T}_{1}$ (KMS@ 0.05\%) & 8.84 & 8.76 & 8.65 & 8.00 & 7.10 & 6.62 & 6.00 \\
\hline $\mathrm{T}_{2}(\mathrm{KMS} @ 0.1 \%)$ & 8.83 & 8.78 & 8.68 & 8.22 & 7.43 & 6.72 & 6.13 \\
\hline $\mathrm{T}_{3}(\mathrm{SB} @ 0.05 \%)$ & 8.83 & 8.70 & 8.65 & 8.20 & 7.41 & 6.68 & 6.03 \\
\hline $\mathrm{T}_{4}(\mathrm{SB} @ 0.1 \%)$ & 8.81 & 8.79 & 8.69 & 8.24 & 7.41 & 6.65 & 6.09 \\
\hline $\mathrm{T}_{5}(\mathrm{SMS} @ 0.05 \%)$ & 8.82 & 8.75 & 8.64 & 8.21 & 7.39 & 6.63 & 6.09 \\
\hline $\mathrm{T}_{6}(\mathrm{SMS} @ 0.1 \%)$ & 8.85 & 8.80 & 8.70 & 8.20 & 7.40 & 6.65 & 6.02 \\
\hline $\mathrm{T}_{7}(\mathrm{PS} @ 0.05 \%)$ & 8.83 & 8.78 & 8.68 & 8.18 & 7.38 & 6.54 & 5.81 \\
\hline $\mathrm{T}_{8}$ (PS@0.1\%) & 8.80 & 8.77 & 8.66 & 8.13 & 7.26 & 6.70 & 6.00 \\
\hline $\mathrm{T}_{9}$ (SB+PS@0.05\% each) & 8.80 & 8.72 & 8.66 & 8.22 & 7.45 & 6.70 & 6.10 \\
\hline $\mathrm{T}_{10}(\mathrm{KMS}+\mathrm{PS} @ 0.05 \%$ each $)$ & 8.81 & 8.66 & 8.69 & 8.23 & 7.42 & 6.70 & 6.07 \\
\hline $\mathrm{T}_{11}(\mathrm{SMS}+\mathrm{PS} @ 0.05 \%$ each$)$ & 8.82 & 8.77 & 8.65 & 8.22 & 7.40 & 6.65 & 5.89 \\
\hline $\mathrm{T}_{12}$ (Refrigeration $\left(4 \pm 2^{\circ} \mathrm{C}\right)$ & 8.83 & 8.78 & 8.68 & 8.18 & 7.38 & 6.54 & 6.10 \\
\hline $\mathrm{T}_{13}$ (Frozen storage $\left.-20^{\circ} \mathrm{C}\right)$ & 8.90 & 8.85 & 8.75 & 8.25 & 7.45 & 6.91 & 6.43 \\
\hline SEm \pm & 0.19 & 0.20 & 0.22 & 0.18 & 0.12 & 0.06 & 0.10 \\
\hline C.D. $(\mathrm{P}=0.05)$ & NS & NS & NS & NS & NS & 0.18 & 0.28 \\
\hline
\end{tabular}

Table.4 Effect of different preservatives and temperatures on flavour of Mango pulp during storage

\begin{tabular}{lccccccc}
\hline Treatments & \multicolumn{7}{c}{ Storage duration (days) } \\
\cline { 2 - 8 } & $\mathbf{0}$ & $\mathbf{1 5}$ & $\mathbf{3 0}$ & $\mathbf{4 5}$ & $\mathbf{6 0}$ & $\mathbf{7 5}$ & $\mathbf{9 0}$ \\
\hline $\mathrm{T}_{1}$ (KMS@ 0.05\%) & 8.70 & 8.82 & 8.73 & 8.53 & 8.00 & 7.19 & 5.60 \\
$\mathrm{~T}_{2}$ (KMS@ 0.1\%) & 8.93 & 8.84 & 8.74 & 8.55 & 8.04 & 7.24 & 6.24 \\
$\mathrm{~T}_{3}$ (SB @ 0.05\%) & 8.83 & 8.75 & 8.69 & 8.35 & 7.50 & 7.19 & 6.00 \\
$\mathrm{~T}_{4}$ (SB @ 0.1\%) & 8.85 & 8.77 & 8.71 & 8.50 & 8.01 & 7.21 & 6.21 \\
$\mathrm{~T}_{5}$ (SMS@ 0.05\%) & 8.86 & 8.76 & 8.67 & 8.50 & 8.14 & 7.10 & 5.50 \\
$\mathrm{~T}_{6}$ (SMS@ 0.1\%) & 8.90 & 8.80 & 8.69 & 8.53 & 8.20 & 7.28 & 6.19 \\
$\mathrm{~T}_{7}$ (PS@ 0.05\%) & 8.75 & 8.74 & 8.64 & 8.44 & 7.95 & 6.18 & 5.14 \\
$\mathrm{~T}_{8}$ (PS@ 0.1\%) & 8.80 & 8.74 & 8.67 & 8.45 & 7.94 & 6.20 & 5.30 \\
$\mathrm{~T}_{9}$ (SB+PS@ 0.05\% each) & 8.81 & 8.76 & 8.67 & 8.47 & 7.80 & 7.20 & 6.00 \\
$\mathrm{~T}_{10}$ (KMS+PS@ 0.05\% each) & 8.87 & 8.80 & 8.68 & 8.52 & 8.02 & 7.22 & 6.22 \\
$\mathrm{~T}_{11}$ (SMS+PS@ 0.05\% each) & 8.81 & 8.76 & 8.69 & 8.49 & 7.99 & 7.30 & 5.60 \\
$\mathrm{~T}_{12}$ (Refrigeration $\left(4 \pm 2^{\circ} \mathrm{C}\right.$ ) & 8.97 & 8.91 & 8.80 & 8.54 & 8.00 & 7.10 & 6.10 \\
$\mathrm{~T}_{13}$ (Frozen storage -20 & 8.98 C) & 8.93 & 8.81 & 8.61 & 8.10 & 7.30 & 6.30 \\
SEm \pm & 0.19 & 0.20 & 0.22 & 0.19 & 0.13 & 0.13 & 0.13 \\
C.D. (P=0.05) & NS & NS & NS & NS & NS & 0.37 & 0.39 \\
\hline
\end{tabular}

Table.5 Effect of different preservatives and temperatures on aroma of Mango pulp during storage

\begin{tabular}{|c|c|c|c|c|c|c|c|}
\hline \multirow[t]{2}{*}{ Treatments } & \multicolumn{7}{|c|}{ Storage duration (days) } \\
\hline & $\mathbf{0}$ & 15 & 30 & 45 & 60 & 75 & 90 \\
\hline $\mathrm{T}_{1}$ (KMS@ 0.05\%) & 6.85 & 6.83 & 6.71 & 6.60 & 6.55 & 6.24 & 6.01 \\
\hline $\mathrm{T}_{2}$ (KMS@0.1\%) & 6.85 & 6.84 & 6.73 & 6.63 & 6.53 & 6.28 & 6.08 \\
\hline $\mathrm{T}_{3}(\mathrm{SB} @ 0.05 \%)$ & 6.83 & 6.80 & 6.70 & 6.60 & 6.45 & 6.20 & 6.00 \\
\hline $\mathrm{T}_{4}(\mathrm{SB} @ 0.1 \%$ ) & 6.82 & 6.81 & 6.71 & 6.60 & 6.50 & 6.24 & 6.04 \\
\hline $\mathrm{T}_{5}$ (SMS@0.05\%) & 6.81 & 6.79 & 6.73 & 6.56 & 6.49 & 6.00 & 5.90 \\
\hline $\mathrm{T}_{6}(\mathrm{SMS} @ 0.1 \%)$ & 6.82 & 6.80 & 6.75 & 6.58 & 6.50 & 6.10 & 6.00 \\
\hline $\mathrm{T}_{7}(\mathrm{PS} @ 0.05 \%)$ & 6.81 & 6.80 & 6.70 & 6.59 & 6.50 & 6.20 & 6.00 \\
\hline $\mathrm{T}_{8}$ (PS@0.1\%) & 6.83 & 6.81 & 6.72 & 6.61 & 6.51 & 6.25 & 6.05 \\
\hline $\mathrm{T}_{9}$ (SB+PS@0.05\% each) & 6.79 & 6.78 & 6.66 & 6.56 & 6.46 & 6.21 & 6.00 \\
\hline $\mathrm{T}_{10}(\mathrm{KMS}+\mathrm{PS} @ 0.05 \%$ each $)$ & 6.80 & 6.79 & 6.69 & 6.59 & 6.49 & 6.23 & 6.00 \\
\hline $\mathrm{T}_{11}(\mathrm{SMS}+\mathrm{PS} @ 0.05 \%$ each$)$ & 6.79 & 6.79 & 6.68 & 6.57 & 6.50 & 6.21 & 6.00 \\
\hline $\mathrm{T}_{12}$ (Refrigeration $\left(4 \pm 2^{\circ} \mathrm{C}\right)$ & 6.90 & 6.88 & 6.77 & 6.70 & 6.60 & 6.30 & 6.10 \\
\hline $\mathrm{T}_{13}$ (Frozen storage $-20^{\circ} \mathrm{C}$ ) & 6.90 & 6.89 & 6.78 & 6.70 & 6.60 & 6.32 & 6.12 \\
\hline $\mathrm{SEm} \pm$ & 0.15 & 0.15 & 0.17 & 0.15 & 0.11 & 0.06 & 0.04 \\
\hline C.D. $(\mathrm{P}=0.05)$ & NS & NS & NS & NS & NS & 0.16 & 0.11 \\
\hline
\end{tabular}




\section{Sensory evaluation of mango pulp}

Organoleptic evaluation of the pulp samples was carried out for taste, flavor and aroma. It is evident that addition of chemical preservatives greatly influences these attributes with a little loss in pulp quality (Tables 3, 4 and 5). The results pertaining to the effect of addition of chemical preservatives to mango pulp are presented in (Tables 3, 4 and 5) for taste, flavor and aroma respectively. The results show that maximum value for taste, flavor and aroma of mango pulp, maximum mean score was observed under mango pulp stored at $-20^{\circ} \mathrm{C}$ which resulted in minimum loss of flavor, aroma and taste of the pulp.

However, loss in sensory qualities may be due to increased acidity and caramelization, and oxidation activities during storage with a course of time. Yadav et al., (2017) observed similar results where minimum loss of flavor was observed in frozen storage at $-20^{\circ} \mathrm{C}$ and Khan et al., (2014) also observed same results for strawberry jam.

Our result confirms that the loss of flavour and taste may be due to the degradation of ascorbic acid and furfural production (Shimoda and Osajima, 1981; Perez and Sanz, 2001)

Thus mango pulp preservation under low temperature $\left(-20^{\circ} \mathrm{C}\right.$ and $\left.4 \pm 2^{\circ} \mathrm{C}\right)$ gave superior quality during the storage, frozen storage at $20^{\circ} \mathrm{C}$ was found best from health point of view as compared to the chemical preservatives and may be recommended for the storage of mango pulp. The effect of low temperature and frozen storage on microflora and organ oloeptic properties of stored mango pulp shown in this work constitutes a major contribution that can help the development of a safer and viable storage of mango pulp at industrial scale.

\section{References}

Amerine, M.A., Pangborn, R.M. and Rocssler, E.B. 1965. Principles of Sensory Evaluation of Food. Academic Press, London.

Ayub, M., Ullah, J., Muhammad, A. and Zeb, A. 2010. Evaluation of strawberry juice preserved with chemical preservatives at refrigeration temperature. International Journal of Nutrition and Metabolism, 2(2):27-32.

Durrani, Y., Zeb, A., Ayub, M., Ullah, W. and Muhammad, A. 2011. Sensory evaluation of mango (Chaunsa) pulp preserved with addition of selected chemical preservatives and antioxidant during storage. Sarhad Journal of Agriculture, 27(3): 471-475.

Fisher, R.A. 1950. Statistical Methods for Research Works. Oliver and Boyd. Edinburgh.

Hashmi, M.S., Alam, S., Riaz, A. and Shah, A.S. 2007. Studies on microbial and sensory quality of mango pulp storage with chemical preservatives. Pakistan Journal of Nutrition, 6(1): 85-88.

Khan, U., Ullah, J., Saeed, B. and Ali, F. 2014. Effect of potassium sorbate and sodium benzoate on the quality and shelf-life of strawberry jam during storage. Journals of Agricultural and Biological Sciences, 9(12): 454-458.

Khattak, J.Z.K., Hussain, A., Ahmad, B., Rehman, M.F., Ullah, Z., Arshad, H. and Hussain, A. 2014. Microbiological stability of chemically preserved apricot pulp. International Journal of Advancements in Life Sciences, 1(3): 153-159.

Perez, A.G. and Sanz, C. 2001. Effect of high oxygen and high carbon- dioxide atmospheres on strawberry flavour and other quality traits. Journal of Agricultural Food Chemistry, 49: 29212930. 
Saxena, M., Bhattacharya, S. and Malhotra, S.K. 2015. Horticultural statistics at a glance 2015. Oxford university press, New Delhi, p.186.

Shimoda, M. and Osajima, Y. 1981. Studies on off-flavour formed during storage of Satsuma mandarin juice. Journal of Agricultural Chemistry, 55: 319-324.

Sivakumar, D., Jiang, Y. and Yahia, E.M. 2011. Maintaining mango (Mangifera indica L.) fruit quality during the export chain. Food Research International,
44(5): 1254-1263.

Tharanathan, R.N., Yashoda, H. M. and Prabha, T. N. 2006. Mango (Mangifera indica L.), the king of fruits-An overview. Food Reviews International, 22(2): 62-65.

Yadav, S.K., Sarolia, D.K., Pilania, S., Meena, H.R. and Mahawer, L.N. 2017. Studies on keeping quality of preserved guava pulp during storage. International Journal of Current Microbiology and Applied Sciences, 6(3): 1235-1242.

\section{How to cite this article:}

Manisha Jangir, Virendra Singh, Pramila Kumari, Sukhdev Singh and Deepak Kumar Sarolia. 2017. Microbiological and Sensory Stability of Preserved Mango (Mallika) Pulp during Storage. Int.J.Curr.Microbiol.App.Sci. 6(8): 1973-1979. doi: https://doi.org/10.20546/ijcmas.2017.608.234 